\title{
Theoretical Surgery: A New Specialty in Operative Medicine
}

\author{
Wilfried Lorenz, M.D., and Matthias Rothmund, M.D. \\ Institute of Theoretical Surgery and Department of Surgery, Center of Operative Medicine I, Philipps University Marburg/Lahn, Federal \\ Republic of Germany
}

\begin{abstract}
Theoretical surgery is defined as a nonoperative decision analysis and clinical and basic research supporting system for surgery. It developed to meet the needs of academic surgeons to coordinate communication with basic science disciplines.

This article summarizes the development of this idea at the University of Marburg where theoretical surgery has reached departmental and institutional proportions. Its objectives and methods are described. Central to its operation are permanent working teams of 2 clinical surgeons, 1 basic scientist (theoretical surgeon), 1-2 technicians, and 1-2 students focusing on one problem in a joint interdisciplinary manner. Decision analysis with classification methods and the creation of decision trees and algorithms are central to the operation of this experiment.

Lessons learned from this academic experiment and the accomplishments during the past 20 years are summarized on 3 levels of efficacy: performance, changing strategies, and outcome.
\end{abstract}

Theoretical surgery started in response to the requests of clinical surgeons and anesthetists in Munich for help with practical clinical problems. In 1968, the concept materialized as 2 small permanent working teams [1, 2] of clinicians and biochemists (Table 1). A few years later, the idea was further organized as a system to perform surgical research for a nondepartmentalized university clinic in Marburg. From the beginning, both surgeons and basic scientists participated in the so-called Marburg experiment [3]. First known by the more traditional title, "Department of Experimental Surgery and Pathological Biochemistry," it was later called the "Institute of Theoretical Surgery" after it developed a permanent working team devoted to the study and practice of medical decision making [4].

The Institute has gradually grown, integrating its work with the Department of Surgery (abdominal, thoracic, endocrine, and pediatric surgery) and the Department of Trauma Surgery (mainly orthopedic surgery related to trauma) and cooperating

Part of this work was reported at the First Congress on Surgical Efficiency and Economy, August 31-September 4, 1987, Lund, Sweden.

Supported by grant of Deutsche Forschungsgemeinschaft (Lo 199/ 14-3).

Dedicated to Alfred Doenicke on the occasion of his 60th birthday. Reprint requests: Wilfried Lorenz, M.D., Institute of Theoretical Surgery, Center of Operative Medicine I, Philipps University Marburg, Baldingerstraße, D-3550 Marburg/Lahn, Federal Republic of Germany. with the Departments of Neurosurgery, Anesthesiology, and Intensive Care. As an independent unit, it was combined with surgery, trauma surgery, and neurosurgery in the Center of Operative Medicine I of Marburg University. Obviously, the transition over 20 years did not occur, as some critics claim, simply as an attempt to provide jobs and chairs for basic research for those who were unsuccessful in their own discipline.

This article describes the concept, s:stem, and organizational structures of theoretical surgery, training of theoretical surgeons, and accomplishments of the system in clinical decision analysis and clinical and basic research in operative medicine, anesthesiology, and intensive care.

\section{Concept of Theoretical Surgery}

Theoretical surgery is defined as a nonoperative decision analysis and clinical and basic research supporting system for surgery. It consists of an essential, predominant integration concept completed by a supplementary cooperation concept.

\section{Integration Concept}

The integration concept is best illustrated by 2 operational networks (Figs. 1, 2). Fig. 1 depicts the current situation in the Federal Republic of Germany [5] where, lacking departments of theoretical surgery, the various elements are expected to function simply by cooperation. Under this system, the academic surgeon, who spends the majority of his/her time and efforts in the operating room and in taking care of patients, is often overwhelmed by the complexity and confusion of existing information channels [5]. It is difficult to communicate with biostatisticians, pharmacologists, physiologists, and social scientists. Academic surgeons also find progressively less time for teaching. If they choose to do research, they become isolated in ivory towers of basic research and soon lose contact and, not long after, credibility as clinical surgeons. They may be familiar with terms such as diagnostic classification matrices, ROC (receiver operator characteristic) curves, multivariate models, and stepwise regression analysis, but unfamiliar with the everyday problems of clinical surgery. We refer to this as the cooperation concept. 

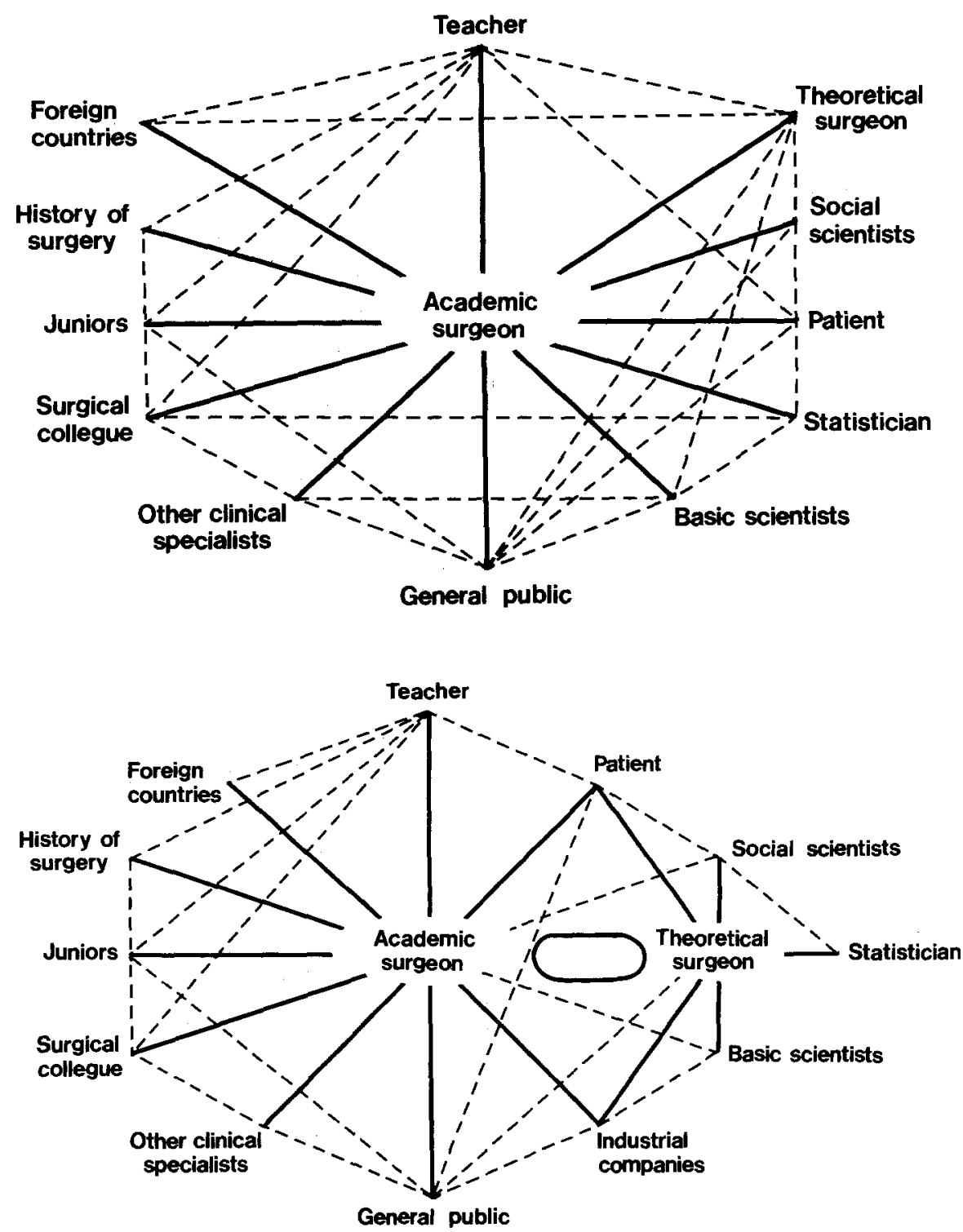

Fig. 1. Classic operational network illustrating direct communication (solid lines) and indirect communication (dotted lines) between academic surgeons and those in other specialties.

Fig. 2. Interposition of theoretical surgery in the operational network in order to integrate and enhance communication.
Table 1. Time table for the development of theoretical surgery.

\begin{tabular}{ll}
\hline Year & Special event and development \\
\hline 1968 & $\begin{array}{l}\text { First permanent teams in Munich with clinicians and } \\
\text { biochemists } \\
\text { Experimental surgery }\end{array}$ \\
1970 & $\begin{array}{l}\text { Concept of Marburg experiment } \\
\text { Division of Experimental Surgery and Pathological } \\
\text { Biochemistry }\end{array}$ \\
1971 & $\begin{array}{l}\text { Systematic follow-up of peptic ulcer patients } \\
1973\end{array}$ First controlled clinical trial \\
1976 & $\begin{array}{l}\text { First controlled biochemical trial } \\
\text { Theoretical surgery }\end{array}$ \\
1978 & $\begin{array}{l}\text { First permanent team on medical decision making and } \\
\text { statistics }\end{array}$ \\
1979 & $\begin{array}{l}\text { Department of Theoretical Surgery } \\
\text { Permanent Working Party on Clinical Studies (CAS) of } \\
\text { German Surgical Society }\end{array}$ \\
1980 & $\begin{array}{l}\text { Permanent team for metasurgery } \\
\text { Expansion of the system within the Departments of Operative } \\
\text { Medicine and Anesthesia, and Intensive Care }\end{array}$
\end{tabular}

For details, see Lorenz and Röher [4]. Reprinted with permission of publisher.
Fig. 2 illustrates, using the integration concept, how the theoretical surgeon fits into this network and integrates the various players in the system. The theoretical surgeon forms a link between the academic surgeon and the various basic scientists such as biochemists, pharmacologists, immunologists, and social scientists [6]. Conversely, the clinical surgeon enables the theoretical surgeon to contact patients, learn clinical science, and recognize the nearly endless practical dimensions of everyday clinical problems.

Despite explosive growth in techniques of decision analysis during the past 2 decades [7], there has been obvious reluctance for its adoption by most clinicians. For example, the decision trees constructed for clinical application [8] were considered too theoretic for practical use by clinical surgeons: endless discussions arose about the case of vascular insufficiency in a diabetic patient in the chapter on utility analysis [8]. Hence, 3 techniques were tested which were found helpful in breaking down the barrier between clinical surgeons and basic scientists (Table 2). They were accomplished in all the necessary details 
Table 2. Three didactic tricks to introduce decision tree methodology into clinical routine in surgery.

Detailed training in the small permanent teams of the integration concept [4]

Choosing a key clinical problem:

Medical versus surgical treatment of peptic ulcers in the era of $\mathrm{H}_{2-}$ antagonists [9]

Forming connections between the clinician's glossary (indication for operation) and the decision maker's glossary (decision tree) [10]

Table 3. Tasks of the theoretical surgeon: Integration concept.

\begin{tabular}{ll}
\hline Tasks & Examples \\
\hline $\begin{array}{c}\text { Contributions to surgical } \\
\text { decision making }\end{array}$ & $\begin{array}{c}\text { Decision trees, computer-aided diagnosis, } \\
\text { and outcome analysis } \\
\text { Contributions to clinical } \\
\text { trials }\end{array}$ \\
$\begin{array}{c}\text { Basic research in surgery, coordination, and data } \\
\text { analysis } \\
\text { Application of methods and knowledge of } \\
\text { basic science disciplines, with intention } \\
\text { and, therefore, planning to be useful to } \\
\text { surgery }\end{array}$ \\
$\begin{array}{c}\text { Support in medical care } \\
\text { documentation, surgical audit }\end{array}$ \\
$\begin{array}{c}\text { Contributions to the } \\
\text { philosophy of surgery } \\
\text { (metasurgery) }\end{array}$ & $\begin{array}{c}\text { Long-lasting work on epistemiology, } \\
\text { ethics, and social aspects of surgery }\end{array}$ \\
\hline
\end{tabular}

Reprinted with permission of publisher [4].

only in the main functional element of theoretical surgery: the combined group of clinical surgeons and basic scientists who work on a common theme as a permanent working team $[3,4]$. Publications that result from such a cooperative effort have always shared authorship.

\section{Cooperation Concept}

The cooperation concept depicted in Fig. 2, unfortunately, does not yet exist for those clinical surgeons in the 3 clinical departments of the Center of Operative Medicine who are not privileged by being incorporated in one of the permanent working teams. This supplementary concept, however, has been improved by a series of service functions provided by the faculty of the Institute.

\section{System of Theoretical Surgery}

Theoretical surgery as an integration concept is best described by the tasks that are transmitted to the theoretical surgeon in the Center of Operative Medicine (Table 3).

\section{Contributions to Surgical Decision Making}

In weekly joint meetings of the permanent working teams, decision trees for treating clinical problems such as duodenal ulcer are created. Fig. 3 illustrates such a graphic representation of a decision problem at hand that shows the expected outcomes at each pivotal decision point $[9,10]$. Other examples are actions and strategies selected in upper gastrointestinal bleeding [11]. These systems use sophisticated computer hardware and software and select several statistical models [11-13].

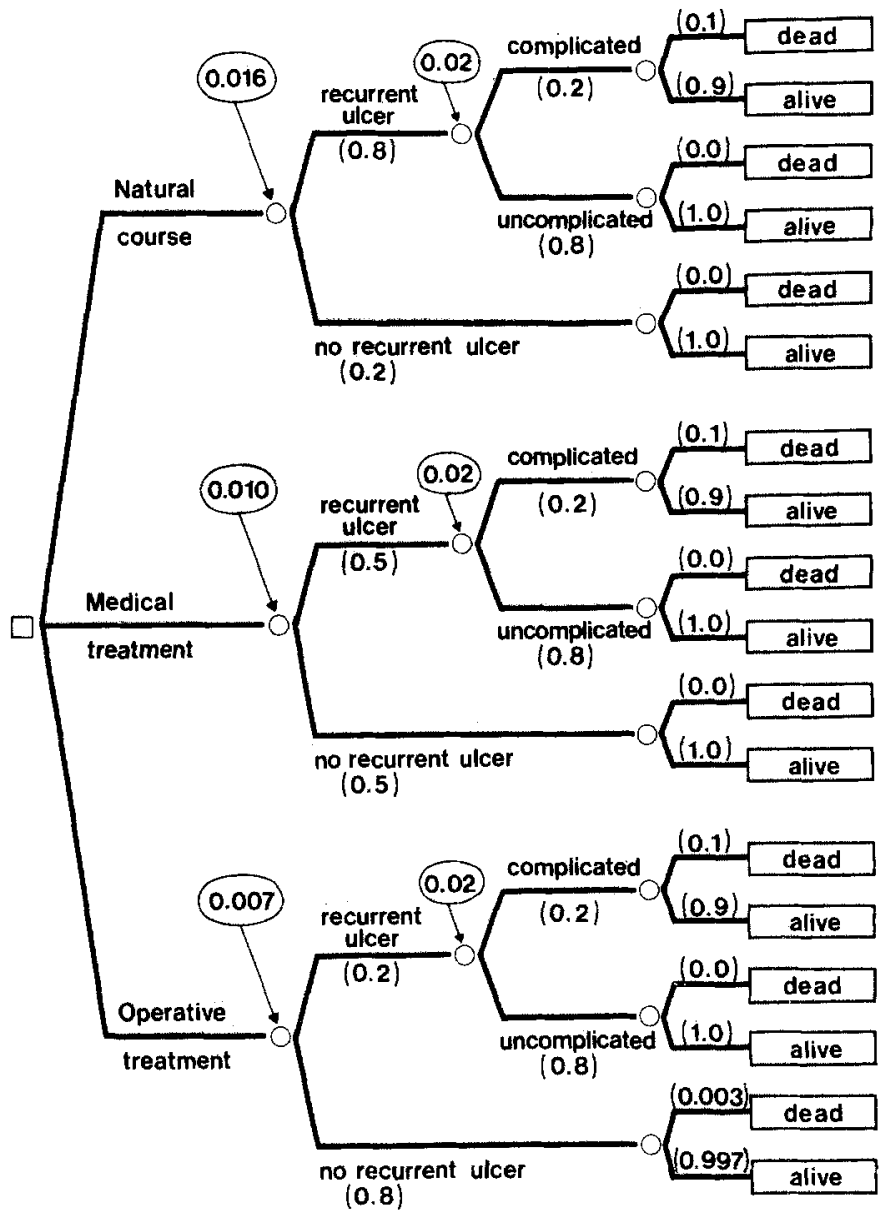

Fig. 3. Example of a decision tree created for management of duodenal ulcer. It indicates anticipated results (expected values) of various treatment options and suggests preferred treatment in the form of utility comparisons.

They create programs for measuring various diagnostic test performance characteristics [14]. A major thrust has been in accurate quantification of perioperative risks [15].

\section{Contributions to Clinical Trials}

The Institute of Theoretical Surgery has been instrumental in designing and supervising a number of controlled clinical trials, some of which were generated as a perceived need to fill in gaps in decision making algorithms. Examples of the latter were those on stress ulcer prophylaxis in polytrauma [16] or on the preanesthetic administration of histamine receptor blockers [17].

\section{Basic Research in Surgery}

Research in biochemistry and pharmacology performed in the permanent working teams is always aimed to be immediately useful for clinical care. It consists of applied research. An example was related to the pathophysiology of duodenal ulcer in carefully controlled cohort trials [18].

\section{Metaanalysis and Metasurgery}

Metaanalysis comprises a group of new techniques by which clinical problems can be solved using data of patients, animals, 
META-ANALYSIS WITH THE DECISION TREE

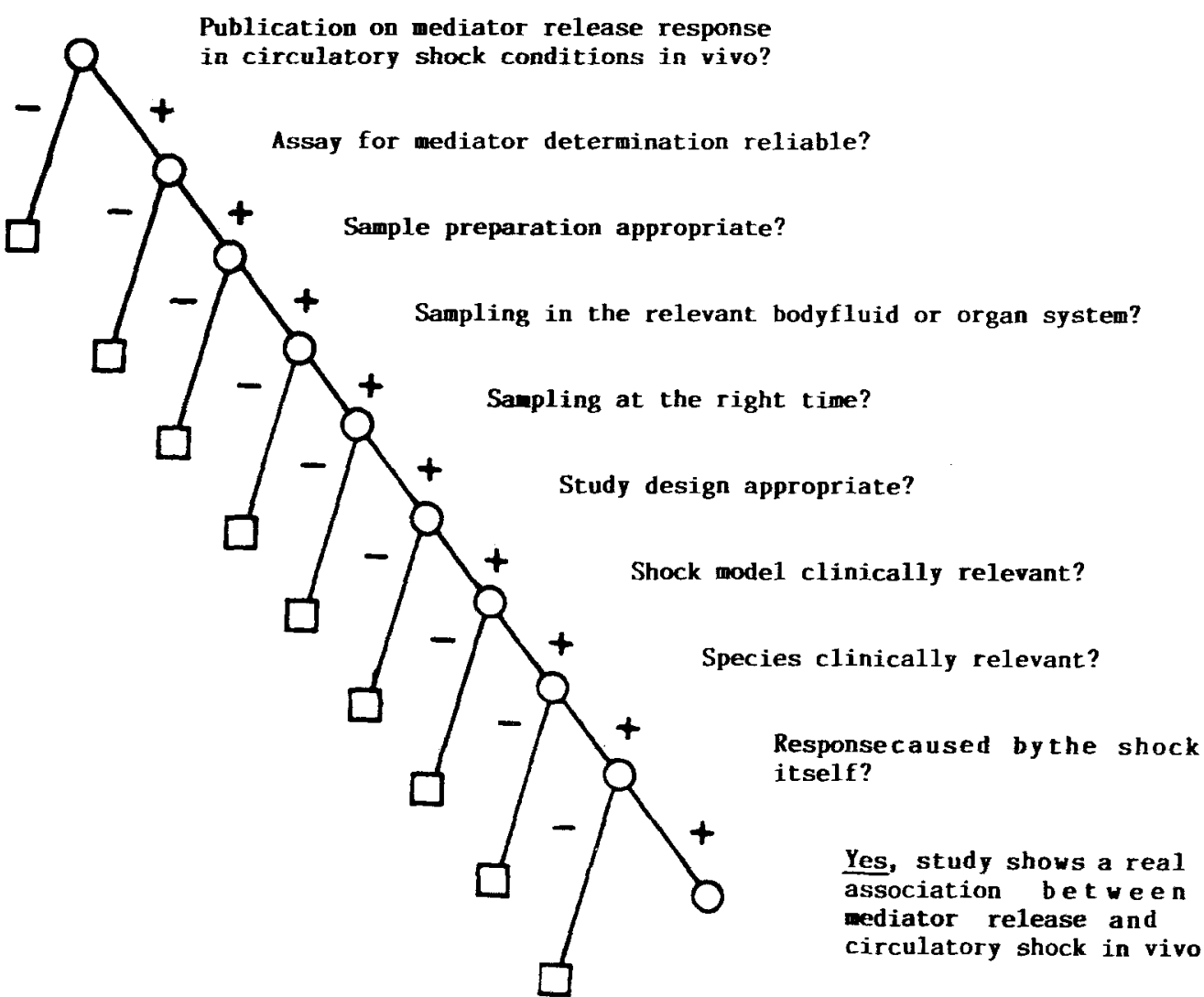

Fig. 4. Graphic representation of how metaanalysis with a decision tree offers rules to detect valid correlations between 2 reported variables. This is a prerequisite for analyzing causal relationship. The example pertains to the relationship of histamine release and septic/endotoxic shock.

Table 4. Tasks of the theoretical surgeon: Cooperation concept.

\begin{tabular}{ll}
\hline Tasks & Examples \\
\hline Advice & $\begin{array}{l}\text { Designing clinical trials, statistics, computer } \\
\text { applications } \\
\text { Local ethical committee } \\
\text { Purchase and maintenance of equipment } \\
\text { Regional and supraregional information retrieval } \\
\text { systems } \\
\text { Central department of medical illustration } \\
\text { Central animal laboratories }\end{array}$ \\
Surveillance & $\begin{array}{l}\text { Radiation, data, and animal protection } \\
\text { Teaching } \\
\text { Traing of postgraduates and students in methods of } \\
\text { theoretical surgery }\end{array}$ \\
\hline
\end{tabular}

cells, etc. not from a single trial, but from a series of studies published in the literature [19]. As a first step, a study design has to be developed with specific rules [e.g., in a decision tree (Fig. 4)] by which the individual trials will be collected from huge data bases, the individual study will be analyzed in detail, and, finally, the whole body of trials will be submitted to descriptive and very sophisticated inferential statistics.

Metasurgery, on the other hand, comprises all systematic studies on the philosophy of surgery including epistemiology, ethics, and social and psychometric aspects of surgery $[5,20]$. The increasing recent emphasis for considering these kinds of problems in surgical decision making has created a new demand
Table 5. Organization of permanent working teams in theoretical surgery.

\begin{tabular}{|c|c|}
\hline Principle & $\begin{array}{l}\text { Integration of decision analysis and clinical } \\
\text { and basic research among surgeons and } \\
\text { theoretical surgeons in a practical, long- } \\
\text { lasting arrangement }\end{array}$ \\
\hline Composition & $\begin{array}{l}1 \text { senior and } 1 \text { junior surgeon } \\
1 \text { basic scientist } \\
1-2 \text { technicians (electronic data processing } \\
\text { and biomedical assistant) } \\
\text { I-2 students (medicine, biology, or chemistry) }\end{array}$ \\
\hline Functions & $\begin{array}{l}\text { Decision analysis and research in a defined } \\
\text { part of the clinical and research program of } \\
\text { the } 2 \text { departments } \\
\text { Communicating at least once a week in a } \\
\text { fixed meeting of about } 2 \text { hours } \\
\text { Applying methods of decision making to } \\
\text { current problems } \\
\text { Designing and conducting clinical trials and } \\
\text { animal experiments } \\
\text { Running a systematic follow-up [23] } \\
\text { Documenting records, experimental data sets, } \\
\text { and literature in the specific field }\end{array}$ \\
\hline Rooms and equipment & $\begin{array}{l}1 \text { room for meetings, for storing hard copies } \\
\text { of records and data sets and literature files } \\
1 \text { laboratory with a microcomputer (LAN) } \\
\text { and other (mostly biochemical) equipment } \\
\text { Rooms provided by the theoretical surgeon, but } \\
\text { access to all apparatus of both departments }\end{array}$ \\
\hline
\end{tabular}

Modified with permission of publisher [3, 4]. 
Table 6. Permanent working teams in theoretical surgery (by 1988).

\begin{tabular}{|c|c|c|c|c|}
\hline No. & $\begin{array}{l}\text { Start } \\
\text { (year) }\end{array}$ & $\begin{array}{l}\text { Special working program } \\
\text { (functions according to table 5) }\end{array}$ & $\begin{array}{l}\text { Surgeons and anesthetists } \\
\text { (surnames) }\end{array}$ & $\begin{array}{l}\text { Basic research scientists } \\
\text { (surnames) }\end{array}$ \\
\hline 1 & 1968 & $\begin{array}{l}\text { Perioperative risk } \\
\quad \text { (interaction between surgery and anesthesia) }\end{array}$ & $\begin{array}{l}\text { Doenicke, Messmer } \\
\text { Thermann, Hamelmann } \\
\text { Schöning, Röher } \\
\text { Dietz, Rothmund }\end{array}$ & Lorenz, Ennis \\
\hline 2 & 1969 & Peptic ulcer surgery & $\begin{array}{l}\text { Feifel, Zenker } \\
\text { Troidl, Seidel } \\
\text { Rohde, Fischer } \\
\text { Thon, Stöltzing } \\
\text { Lindlar, Wagner }\end{array}$ & Lorenz, Barth \\
\hline 3 & 1969 & $\begin{array}{l}\text { Intestinal surgery including ischemia } \\
\text { (stress ulcer, ileus, colorectal surgery, } \\
\text { technology assessment, sonography) }\end{array}$ & $\begin{array}{l}\text { Feifel } \\
\text { Richter, Stahlknecht } \\
\text { Hesterberg } \\
\text { Klotter }\end{array}$ & $\begin{array}{l}\text { Lorenz } \\
\text { Kusche, Reimann } \\
\text { Sattler }\end{array}$ \\
\hline 4 & 1978 & $\begin{array}{l}\text { Upper gastrointestinal bleeding } \\
\text { (medical decision making) }\end{array}$ & $\begin{array}{l}\text { Rohde, Thon } \\
\text { Stöltzing } \\
\text { Lindlar, Wagner }\end{array}$ & $\begin{array}{l}\text { Ohmann } \\
\text { Sitter }\end{array}$ \\
\hline 5 & 1980 & $\begin{array}{l}\text { Sepsis and septic shock } \\
\text { (peritonitis, pancreatitis) }\end{array}$ & $\begin{array}{l}\text { Horeyseck, Dietz } \\
\text { Maroske, Schirren } \\
\text { Lennartz }\end{array}$ & Neugebauer \\
\hline 6 & 1982 & $\begin{array}{l}\text { Metasurgery } \\
\quad \text { (epistemiology, ethics, sociology) }\end{array}$ & $\begin{array}{l}\text { Röher } \\
\text { Rothmund }\end{array}$ & Lorenz, Schult \\
\hline 7 & 1986 & $\begin{array}{l}\text { Inflammatory mediators after knee injuries } \\
\text { and road accidents }\end{array}$ & $\begin{array}{l}\text { Echtermeyer } \\
\text { Knaebler, Sangmeister } \\
\text { Gotzen }\end{array}$ & Ennis \\
\hline
\end{tabular}

Names are ordered in time sequence of entering the teams. New lines usually mean stopping the work with the foregoing persons.

for more solid data bases and for professional techniques already available in social and behavioral sciences and in arts and humanities upon which such decisions must be formed. This has been actively pursued by creating a permanent working team on metasurgery [4].

Theoretical surgery as a supplementary, but improved cooperation concept is also best described by the tasks transmitted to the theoretical surgeon (service and management functions in the entire Center of Operative Medicine I, Department of Anesthesiology, and Intensive Care) (Table 4).

\section{Advice}

The Theoretical Surgery Department provides support in clinical trials, participation in the local ethics committee, recommendations concerning the purchase and maintenance of special biochemical and electronic data processing equipment and software, and coordination of the various department activities in a central data processing unit.

\section{Service Functions}

They include providing clinical surgeons with information from retrieval systems including access into existing departmental [19], local, and international systems such as Medlars. The permanent working team dealing with metasurgery employs a trained librarian, complete hard disc facilities, and an assistant who is available for all technical and operational information transfer functions such as photocopies and duplicating services.

\section{Surveillance Functions}

These include radiation, and data and animal protection. By creating a computerized system of medical decision making,
Table 7. Rules for theoretical surgeons and surgeons to achieve successful communication and progress of work in the permanent working teams.

\begin{tabular}{|c|c|}
\hline Category & Specification \\
\hline \multirow[t]{3}{*}{ Psychological } & $\begin{array}{l}\text { Intention and sense of duty to communicate and work } \\
\text { in a team }\end{array}$ \\
\hline & $\begin{array}{l}\text { Acceptance of different roles in treating the patients: } \\
\text { the surgeon is the king, the theoretical surgeon is } \\
\text { the Brahman }\end{array}$ \\
\hline & Fairness in authorship \\
\hline \multirow[t]{6}{*}{ Scientific } & $\begin{array}{l}\text { Careful selection of persons for the specific topic of } \\
\text { the team }\end{array}$ \\
\hline & $\begin{array}{l}\text { Finding a common terminology between the clinician } \\
\text { and the basic scientist by subtle exchange of } \\
\text { information }\end{array}$ \\
\hline & Mutual training in clinical science and basic research \\
\hline & $\begin{array}{l}\text { Combining special objectives with general } \\
\text { methodological framework in selecting research } \\
\text { fields to avoid superspecialization }\end{array}$ \\
\hline & $\begin{array}{l}\text { Flexibility in research fields to cope with unavoidable } \\
\text { changes in hospital staff }\end{array}$ \\
\hline & $\begin{array}{l}\text { Patience of the theoretical surgeon to achieve } \\
\text { harmony in argumentation after an exchange of } \\
\text { staff: The surgeon must treat the patients on the } \\
\text { first day of starting work in the new hospital }\end{array}$ \\
\hline \multirow[t]{5}{*}{ Practical } & $\begin{array}{l}\text { Selection of an appropriate date for the weekly } \\
\text { meeting-a matter of test and retest until it works }\end{array}$ \\
\hline & $\begin{array}{l}\text { Insistent fights by the theoretical surgeon to keep the } \\
\text { meetings going-even if the surgeon is tired }\end{array}$ \\
\hline & Careful preparation of an agenda for the weekly meeting \\
\hline & Theoretical surgeon: Always approach the surgeon! \\
\hline & $\begin{array}{l}\text { Don't wait for the surgeon, the surgeon is always } \\
\text { busy! }\end{array}$ \\
\hline
\end{tabular}

theoretical surgery reduced 10 -fold the number of studies based on animal experiments [21] without diminishing the research productivity of the program. Such effectiveness is a potent argument for promoting medical decision making. 


\section{Teaching and Training}

Faculty members of the Institute are involved in a weekly 2-hour training seminar for all departments of the Center of Operative Medicine I and in teaching students in the surgical curriculum. Topics on medical decision making and clinical biostatistics are listed in previous papers [3, 4].

\section{Organizational Structures in Theoretical Surgery}

It is a key function in the system of theoretical surgery that the organizational elements include both departmental and interdepartmental structures. They reflect the objectives that integrate the efforts of clinical surgeons and basic scientists.

\section{Interdepartmental Structure}

The operational basis of theoretical surgery relies on an interdepartmental structure, and the permanent working teams (Table 5). These teams are permanent in order to provide sustained development of an investigative approach. They are small (4-8 members) in order to encourage easy communication and to stimulate individual effort. A small size simplifies cooperative efforts with others.

Existing permanent working teams are listed in Table 6 . The years in which each project began are presented in order to demonstrate how the concept and system of theoretical surgery stimulated new problems. Focus for study is obviously diverse $[3,4,21]$. Some teams have shifted their interest over the years of this experiment (e.g., no. 3), and, of course, there has been a good deal of change in personnel (e.g., nos. 1-3). Despite such inevitable change, the primary thrust of the permanent working teams has remained constant. Of the 43 clinical surgeons in the Center of Operative Medicine I, 14 are currently members of a permanent working team (Table 6). The remainder are either in a wait-and-see position (less than 3 years in postgraduate surgical training), handle their own research projects (not very common), or are not interested in an academic career. All of them participate in the weekly training seminar and often informally in discussions (part of the cooperation concept).

We have learned from both our successes and failures during this 20-year experience. Some of our conclusions are listed in Table 7. As would be anticipated in a multidisciplinary effort, communication is essential. Meetings of the teams are held on Wednesday or Thursday evening and on Saturday mornings about 25-35 times per year. The benefit to participants is perhaps best illustrated by the fact that this demanding schedule has endured for 20 years!

\section{Departmental Structures}

The faculty and staff of the Institute of Theoretical Surgery, which is administratively and financially independent from the clinical departments, consist of 8 basic scientists trained in different disciplines (Table 8), 12 half- or full-time technicians for biomedicine or informatics, and 3 administration employees. The hierarchic structure, including a full professor of theoretical surgery, is similar to that of the 3 clinical departments in the Center of Operative Medicine I. At the moment, there are 8 graduate students working in the Institute, which also provides laboratory rooms (Table 5) and most of the
Table 8. Faculty of the Institute of Theoretical Surgery.

\begin{tabular}{|c|c|}
\hline Discipline & Basic scientists covering the field \\
\hline $\begin{array}{l}\text { Statistics and } \\
\text { information studies }\end{array}$ & $\begin{array}{l}1 \text { mathematician }[\mathrm{Ph} . \mathrm{D} \text {. in mathematics, } \\
\left.\left.\text { preclinical studies in medicine (Physikum }{ }^{\mathrm{a}}\right)\right] \\
1 \text { computer programmer }\end{array}$ \\
\hline Clinical pharmacology & $\begin{array}{l}1 \text { physician (authorized to train } \\
\text { pharmacologists) }\end{array}$ \\
\hline Clinical chemistry & $\begin{array}{l}1 \text { clinical chemist (Assistant Professor in } \\
\text { clinical chemistry) }\end{array}$ \\
\hline Biochemistry & $\begin{array}{l}2 \text { chemists [Ph.D. in chemistry, preclinical } \\
\text { and clinical studies in medicine } \\
\left.\text { (praktisches Jahr }{ }^{b}\right) \text { ] }\end{array}$ \\
\hline Cell biology & 1 biochemist (Ph.D. in the British system) \\
\hline $\begin{array}{l}\text { Laboratory animal } \\
\text { science }\end{array}$ & 1 veterinary surgeon \\
\hline
\end{tabular}

Reprinted with permission of publisher [4].

${ }^{a}$ Examination after premedical school.

${ }^{\mathrm{b}}$ Year of practice, final year of medical school.

Table 9. Training and career of a theoretical surgeon.

Fully qualified in one specialty of basic research

Trained by surgeons to acquire reasonably large knowledge ( $6-8$ years) in surgical science and management

Trained by different basic scientists to acquire small knowledge in several basic disciplines

Finally qualified by Habilitation ${ }^{\mathrm{a}}$ (Reader, Assistant Professor, etc.)

${ }^{a}$ Formal permission to act as an academic lecturer (docent or professor).

research budget for the permanent working teams. The total research grant support of the Institute is about 700,000 DM. Spatial conditions comprise about $600 \mathrm{~m}^{2}$ and have been described in detail previously [4].

\section{Training of Theoretical Surgeons}

As the concept of theoretical surgery has emerged, so have our ideas about how to train specialists in this new academic field. It soon became evident that theoretical surgery was problemoriented rather than patient-oriented. As a result, basic scientists had to be taught clinical medicine in a manner different from their basic science training.

Table 9 summarizes the usual career training pattern for those specializing in theoretical surgery. Such a person is usually fully qualified in one specialty of basic research (Table 8) before entering the Institute. Thus, armed with special training, the new faculty member is ready for an education in clinical medicine and usually qualifies at age 35-38 years by the examination procedure of Habilitation to achieve the degree of Assistant Professor.

\section{Accomplishments of Theoretical Surgery}

It is difficult to precisely document and quantitate accomplishments of the Marburg experiment during the past 20 years; however, a legitimate technique is currently assessing the impact of the system on efficacy in clinical care and surgical research using 3 levels according to Loop and Lusted [22] (Table 10).

The influence on existing surgical societies is just now being felt, perhaps epitomized by recognition of the importance of medical decision making in this symposium. The German 
Table 10. Impact of theoretical surgery on efficacy in clinical care and decision analysis, in clinical research, and basic research in surgery.

\begin{tabular}{|c|c|c|c|}
\hline \multirow{2}{*}{$\begin{array}{l}\text { Level of } \\
\text { efficacy }\end{array}$} & \multirow[b]{2}{*}{ Clinical care and decision analysis } & Functions in academic surgery & \multirow[b]{2}{*}{ Basic research } \\
\hline & & Clinical research & \\
\hline \multirow[t]{2}{*}{ Performance } & $\begin{array}{l}\text { Development of safer anesthesia [17] } \\
\text { Perioperative, quantitative risk } \\
\text { assessment by surgeons and } \\
\text { anesthetists [15] } \\
\text { Argumentation in clinical decisions }\end{array}$ & $\begin{array}{l}\text { First prospective clinical trial in } \\
\text { German Surgery, 1973 [24] } \\
\text { More than } 30 \text { randomized trials in } \\
\text { anesthesia, intensive care, and } \\
\text { surgery [15] }\end{array}$ & $\begin{array}{l}\text { Publishing articles in basic research } \\
\text { journals with high impact }(25)\end{array}$ \\
\hline & $\begin{array}{l}\text { with quantities } \\
\text { Defined strategies for peptic ulcer [10], } \\
\text { upper gastrointestinal bleeding [11] } \\
\text { Monitoring steroid levels administered } \\
\text { in septic shock }\end{array}$ & $\begin{array}{l}\text { Cohort studies with simutaneous } \\
\text { controls in peptic ulcer pathogenesis } \\
\text { and surgery [18] and on perioperative } \\
\text { risk [17] } \\
\text { Metaanalysis study on mediators in } \\
\text { septic shock [19] }\end{array}$ & $\begin{array}{l}\text { Publishing articles on metasurgery in } \\
\text { The Lancet }\end{array}$ \\
\hline $\begin{array}{l}\text { Changing } \\
\text { strategies }\end{array}$ & $\begin{array}{l}\text { Indication for operative treatment of } \\
\text { peptic ulcer [10] } \\
\text { Indication for immediate operation in } \\
\quad \text { bleeding ulcer [11] } \\
\text { Stress ulcer prophylaxis [16] } \\
\text { Histamine } \mathrm{H}_{1}-\mathrm{H}_{2} \text {-antagonists in } \\
\text { mesenteric infarction }\end{array}$ & $\begin{array}{l}\text { Tremendous reduction in old-fashioned } \\
\text { retrospective surveys without } \\
\text { controls } \\
\text { Publication of studies mostly in English } \\
\text { journals } \\
\text { Spending much more time in planning } \\
\text { clinical trials before conducting them } \\
\text { and performing rotten statistics }\end{array}$ & $\begin{array}{l}\text { Surgeons are first authors of articles in } \\
\text { basic research } \\
\text { Surgeons report at pharmacology } \\
\text { meetings } \\
\text { Animal models in basic research are } \\
\text { changed by clinical considerations } \\
\text { [17] }\end{array}$ \\
\hline Outcome & $\begin{array}{l}\text { Decrease in lethality in upper } \\
\text { gastrointestinal bleeding }(15 \% \rightarrow 6 \%) \\
{[11]}\end{array}$ & $\begin{array}{l}\text { Highly cited publications including } \\
\text { citation classics [26] } \\
\text { Editorials, invited lectures, and reviews } \\
\text { in standard textbooks as parameters } \\
\text { of common interest } \\
\text { Promotion of careers for surgeons and } \\
\text { theoretical surgeons } \\
\text { Receiving considerable amounts of } \\
\text { money in grants }\end{array}$ & $\begin{array}{l}\text { Reduction of the gap between basic } \\
\text { research and clinical science: Man is } \\
\text { an animal species } \\
\text { Improved designs of studies in basic } \\
\text { research: Randomized trials [18, 19] } \\
\text { More sound statistics in basic research } \\
\text { (protection of the } \alpha \text {-error) }\end{array}$ \\
\hline
\end{tabular}

Society of Surgery established a Permanent Working Party on Clinical Trials (CAS) in 1980 that distributes the idea of theoretical surgery among 200 members. In 1986, J.H. Baron of London helped us start the journal, Theoretical Surgery.

The role of theoretical surgery in furthering the progress of clinical surgery is more subtle. Perhaps the major accomplishment has been impressing an all but reflex critical approach in surgical decision making among our doctors and students at all levels of expertise. Decision analysis is an integral part of theoretical surgery.

\section{Résumé}

La chirurgie théorétique se définit comme un système d'analyse décisionnelle non opératoire associé à un système de recherche clinique et de sciences chirurgicales fondamentales.

Elle est née de la nécessité de trouver un moyen de communication et de correspondance entre la chirurgie académique et les progrès des sciences fondamentales. Cet article résume le développement de cette idée à l'Université de Marburg où la chirurgie théorétique a acquis l'envergure d'une véritable science universitaire. Les objectifs et les méthodes employées sont présentées. Un travail d'ensemble est assuré par une équipe permanente composée de 2 chirurgiens cliniques, d'un professeur de sciences fondamentales (chirurgien théoréticien), d'un ou deux techniciens, et d'un ou deux étudiants travaillant sur un problème de manière interdisciplinaire. L'analyse décisionnelle avec classification des méthodes, et la création d'arbres décisionnels sont essentielles dans le déroulement de l'opération.
Les leçons de cette expérience académique et les résultats obtenus ces 20 dernières années sont résumées selon 3 critères d'efficacité: performance, changement de stratégie, et résultat.

\section{Resumen}

La cirugía teórica es definida como un sistema de soporte del análisis para la toma de decisiones no operativo y de la investigación clínica y básica en cirugía. Fue desarrollado para responder a las necesidades de los cirujanos académicos en cuanto a la capacidad de coordinar la comunicación con las disciplinas científicas básicas.

Este artículo resume el desarrollo de esta idea en la Universidad de Marburgo, donde la cirugía teórica como función institucional ha alcanzado proporciones de departamento y de instituto. Se describen sus objetivos y métodos. Como núcleo central para su operación hay equipos permanentes de trabajo compuestos por 2 cirujanos clínicos, 1 científico básico (cirujano teórico), 1-2 técnicos, y 1-2 estudiantes; cada problema determinado es enfocado por el grupo en forma conjunta e interdisciplinaria. El análisis para la toma de decisiones con métodos de clasificación, y la creación de esquemas o árboles de flujo de decisión y de algorritmos, son de importancia central para la operación de este experimento.

Las lecciones aprendidas en este experimento académico y sus realizaciones en el curso de los últimos 20 años son resumidos en 3 niveles de eficacia: credibilidad, estrategias variables, y resultado. 


\section{Acknowledgment}

We are most grateful to Professor B. Eiseman for his encouraging analysis of theoretical surgery and the many improvements of our manuscript.

\section{References}

1. Zenker, R., Reichel, K., Lorenz, W., Haendle, H., Feifel, G.: Zur Wahl der operativen Eingriffe bei unkomplizierten Magen- und Zwölffingerdarmgeschwüren. Chirurg 39:488, 1968

2. Doenicke, A., Lorenz, W.: Histaminfreisetzung und anaphylaktische Reaktionen bei Narkosen. Biochemische und klinische Aspekte. Anaesthesist 19:413, 1970

3. Lorenz, W., Hamelmann, H., Troidl, H.: Marburg experiment on surgical research: A five-year experience on the cooperation between clinical and theoretical surgeons. Klin. Wochenschr. 54:927, 1976

4. Lorenz, W., Röher, H.D.: Fifteen years of the Marburg experiment on surgical research. Part I: Change from experimental to theoretical surgery. Theor. Surg. $1: 21,1986$

5. Lorenz, W., Röher, H.D.: Entwicklung wissenschaftlicher Aussagen. In Chirurgie im Wandel der Zeit 1945-1983, H.W. Schreiber, G. Carstensen, editors, Berlin-Heidelberg-New York, SpringerVerlag, 1983, pp. 28-35

6. Suttmann, H., Doenicke, A., Lorenz, W., Ennis, M., Müller, O.A., Dorow, R., Ackenheil, M.: Is perioperative stress a real surgical phenomenon or merely a drug-induced effect? Theor. Surg. 1:119, 1986

7. Kassirer, J.P., Moskowitz, A.J., Lau, J., Pauker, G.: Decision Analysis: A Progress Report. Ann. Intern. Med. 106:275, 1987

8. Weinstein, M.C., Fineberg, H.V.: Clinical Decision Analysis, Philadelphia, W.B. Saunders, 1980, pp. 1-351

9. Lorenz, W., Thon, K., Ohmann, C., Röher, H.D.: Symptomloses und kompliziertes Ulcus pepticum als extreme Erscheinungsform der Ulkuskrankheit: Konsequenzen für die Wahl zwischen konservativer und chirurgischer Therapie. Langenbecks Arch. Chir. 366: 69,1985

10. Lorenz, W., Ohmann, C., Stöltzing, H., Thon, K.: Grundlagen chirurgischer Indikationen: Hilfen zur Entscheidungsfindung. Langenbecks Arch. Chir. 369:57, 1986

11. Thon, K., Stöltzing, H., Ohmann, C., Lorenz, W., Röher, H.D.: Medical decision making and clinical problem solving in upper gastrointestinal bleeding. Theor. Surg. 2:185, 1988

12. Ohmann, C., Thon, K., Stöltzing, H., List, E., Zaczyk, R., Ennis, M., Lorenz, W., Röher, H.D.: The personal computer as an aid to documentation of upper gastrointestinal endoscopy. Theor. Surg. $1: 69,1986$

13. Ohmann, C., Yang Qin, Künneke, M., Stöltzing, H., Thon, K., Lorenz, W.: Bayes theorem and conditional dependence of symptoms: Different models applied to data of upper gastrointestinal bleeding. Methods Inf. Med. 27:73, 1988
14. Ohmann, C., Künneke, M., Zaczyk, R., Thon, K., Lorenz, W.: Selection of variables using "Independence Bayes" in computeraided diagnosis of upper gastrointestinal bleeding. Stat. Med. 5:503, 1986

15. Lorenz, W., Dick, W., Junginger, T., Ohmann, C., Doenicke, A., Rothmund, M.: Biomedizinische und klinimetrische Ansätze in der Ursachenforschung beim perioperativen Risiko: Erstellung einer deutschen ASA-Klassifikation. Langenbecks Arch. Chir. 372:199, 1987

16. Lorenz, W., Fischer, M., Rohde, H., Troidl, H., Reimann, H.-J., Ohmann, C.: Histamine and stress ulcer: New components in organizing a sequential trial on cimetidine prophylaxis in seriously ill patients and definition of a special group at risk (severe polytrauma). Klin. Wochenschr. 58:653, 1980

17. Lorenz, W., Doenicke, A.: $\mathrm{H}_{1}+\mathrm{H}_{2}=$ blockade: A prophylactic principle in anaesthesia and surgery against histamine-release responses of any degree of severity. N. Engl. Reg. Allergy Proc. Part I: $6: 37,1985$, Part II: $6: 174,1985$

18. Thon, K.P., Lorenz, W., Ohmann, C., Weber, D., Rohde, H., Röher, H.D.: Sample-taking problems in measuring actual histamine levels of human gastroduodenal mucosa: Specific and general relevance in clinical trials on peptic ulcer pathogenesis and selective proximal vagotomy. Gut 26:1165, 1985

19. Neugebauer, E., Lorenz, W., Maroske, M., Barthlen, W., Ennis, E.: The role of mediators in septic/endotoxic shock. A metaanalysis evaluating the current status of histamine. Theor. Surg. 2: 1,1987

20. Lorenz, W.: Palliative nephrostomy in patients with incurable cancer: The first debate on medical ethics in theoretical surgery. Theor. Surg. $1: 117,1986$

21. Lorenz, W., Troidl, H.: The Marburg Experiment. In Principles and Practice of Research, H. Troidl, W.O. Spitzer, B. McPeek, D.S. Mulder, M.F. McKneally, editors, Berlin-Heidelberg-New York, Springer-Verlag, 1986, pp. 137-148

22. Loop, J.W., Lusted, L.B.: American college of radiology diagnostic efficacy studies. Am. J. Roentgenol. 131:173, 1978

23. Rohde, H., Troidl, H., Lorenz, W.: Systematic follow-up: A concept for evaluation of operative results in duodenal ulcer patients. Klin. Wochenschr. 55:925, 1977

24. Seidel, W., Troidl, H., Lorenz, W., Rohde, H., Richter, H., Drews, H., Hamelmann, H.: Eine prospektive, kontrollierte Studie zur selektiven Vagotomic beim chronischen Duodenalulkus: Frühergebnisse mit einer standardisierten Operationsauswahl und Operationstecknik. Klin. Wochenschr. 51:477, 1973

25. Barth, H., Lorenz, W., Troidl, H.: Effect of amodiaquine on gastric histamine methyltransferase and on histamine stimulated gastric secretion. Br. J. Pharmacol. 55:321, 1975

26. Doenicke, A., Lorenz, W., Beigl, R., Bezecny, H., Uhlig, G., Kalmar, L., Praetorius, B., Mann, G.: Histamine release after intravenous application of short-acting hypnotics: A comparison of etomidate, althesin (CT 1341) and propanidid. Br. J. Anaesth. 45: 1097, 1973 